\title{
From Victor Hugo to Fedor Dostoevskii: 19th-Century Perceptions of Architecture as Historical Text
}

\author{
William C. Brumfield* \\ Tulane University \\ New Orleans, Louisiana, USA
}

Received 14.03.2015, received in revised form 22.04.2015, accepted 10.05.2015

The article examines the 19th-century European perception of architecture - and architectural styleas an expression of history and culture that can only be fully explicated through a verbal, literary text. This concept was particularly active in discussions of national identity. Architecture was both reflective on a national culture and at the same time called upon to further reflect and express that culture. On this basis arose critical interpretations of eclectic, historicist architectural styles. The article discusses the origins of this historicist concept in Victor Hugo's novel Notre Dame de Paris and its elaboration in the work of Nikolai Gogol, Fedor Dostoevsky and the Marquis de Custine.

Keywords: architectural stylization, historicism, eclecticism, Carlo Rossi, Victor Hugo, Notre Dame de Paris, Nikolai Gogol, Aleksei Martynov, Fedor Dostoevsky, Paris, St. Petersburg, Moscow.

Research area: culture studies.

If nationalism is a secular religion, it is appropriate that the revival of medieval architecture in 19th-century European eclecticism involved the transposition of stylistic motifs from religious to secular structures. This is especially evident in late 19th-century Russia, whose masonry architecture before the 18th century consisted almost entirely of churches.

Indeed, it can be argued that certain medieval monuments served as a defining expression of Russian secular identity. The most visible example is Moscow's Cathedral of the Intercession on the Moat, popularly known as Basil the Blessed and referred to in the 16th and 17th centuries as "Jerusalem".1 Built as a votive church in 1555-61 to commemorate Ivan the Terrible's victory over the khanate of Kazan (1552), the structure celebrates the coalescence of Muscovy's role as the defender not only of the Orthodox faith but also of Russia itself. While other Russian churches rarely achieved such connotative density, church architecture (including monasteries) continued to serve until the Petrine era as the repository of national identity in architecture.

However, the rapid secularization of Russian society during the eighteenth century led to a redefining of the role of the church. ${ }^{2}$ This transformation was accompanied by an equally radical change in the design of the church, whose form could bealtered to suit the latestimperial taste,

(C) Siberian Federal University. All rights reserved

* Corresponding author E-mail address: william.brumfield@gmail.com 
from Baroque to neoclassicism. Consequentially, church architecture, like Baroque palaces and neoclassical government buildings, became another category of monumental architecture subordinate to the state and dependent upon it for support. There were occasional concessions to national tradition, as in Bartolomeo Rastrelli's sublimely beautiful Cathedral of the Resurrection at the Smolny Convent, commissioned in the 1740 s by the Empress Elizabeth. ${ }^{3}$ Yet the imperial court, rather than the church, remained the central culture-forming force in an enlightened autocracy.

The equation of state and nation in imperial Russian architecture culminated in the late neoclassical monuments of Carlo Rossi. In 1805, having retunred from a study tour of Europe (Italy in particular), the young Rossi submitted a proposal for the reconstruction of Admitralty Embankment. The project never materialized and Rossi's drawings disappeared; but his note of explanation contains the following passage: "The dimensions of the project proposed by me exceed those accepted by the Romans for their structures. Indeed, why should we fear to be compared with them in magnificence? One should interpret this word not as an abundance of ornament, but rather grandeur of form, nobility of proportion, and solidity. This monument must be eternal."4 Russia's greatness as a nation is here affirmed by a comparison to the heart of western, Roman culture.

Rossi was one of the last of Petersburg's brilliant neoclassicists. As elsewhere in Europe, the concept of a dominant architectural system based on the classical orders - yielded to ideas of local history embodied in architectural style. Instead of universals, Russian intellectuals of the romantic era, like their counterparts elsewhere in Europe, elevated the local, the specifically national. 5 Although classical models continued to be revered, particularly in educational curricula, the competing claims for new tectonic and decorative forms argued for a greater response to function and physical setting, both of which stimulated an eclectic approach based on an appeal to the national character and its cultural heritage.

Paradoxically, early students of Russian architecture often attributed native building traditions to various foreign derivations, as exemplified in the impressionistic generalities of a public lecture delivered in 1837 by Aleksei Martynov (1820-1895), a student at the Moscow Court School of Architecture. 6 The surmises and inaccuracies of Martynov and others are of less significance, however, than their attempt to resurrect a cultural heritage that had for so long seemed invisible.

In 1838 the Petersburg newspaper Khudozhestvennaia gazeta (Arts gazette) complained that Russian academicians were still preoccupied with the monuments of the ancient world, to the detriment of an understanding of Russian architecture and its relation to that of other cultures: "It would be desirable if our architects also turned their attention to the monuments of various times and tastes scattered throughout our provinces."7 An article published in 1840 in the same source proclaimed that "Every climate, every people, every age has its special style, which corresponds to particular needs or satisfies special goals."8 For a growing number of intellectuals, the folk, or narod, was the only authentic base for a modern national culture.

This is a topic with many ramifications for Russian and European history. Indeed, it is associated with the transformation of history as an academic discipline. ${ }^{9}$ In architecture the uses of history in formulating a national sense of identity led to such movements as historicism and eclecticism. 10 Yet the post-classical, eclectic age by definition lacked a guiding system of stylistic rules. The adaptation of ornamental motifs drawn 
from other, often exotic, cultures coexisted with attempts to recreate "national" styles, derived from a renewed appreciation of medieval culture. Perceptions of architectural form became increasingly linked to literary interpretations of history.

One of the earliest writers to consider the cultural significance of European historicism was Victor Hugo, especially in his Notre Dame de Paris, first published in 1831. His "Note Added to the Definitive Edition (1832)" comments both on the decline of contemporary architecture and on the need to preserve historic buildings until a worthier architectural era arrives:

While waiting for new monuments, let us conserve the old monuments. If it is possible, let us inspire in the nation a love for the national architecture. This, the author declares, is one of the principle goals of this book. 11

Paradoxically, Hugo suggests in the book, set in the 1480s, that architecture must inevitably lose the preeminence among the arts that it possessed before the Renaissance. At the end of the first chapter of Book Five, Hugo's possessed archdeacon Don Claude speaks of "reading one after another the marble letters of the alphabet, the granite pages of the book." Having defined the great architecture of the past as man's supreme act of creation and repository of knowledge, he lifts his left hand toward the towers of Notre Dame, places his right on a book printed in 1474 in Nuremberg, and says: "This will kill that. ... The book will kill the building." (172-173)

The meaning of this dark saying is given lengthy elaboration in the following chapter, an authorial digression entitled "Ceci tuera cela." Hugo first interprets this utterance in its most direct sense, as the inevitable conflict between the church and Gutenberg, of the printing press breaking the church's monolopy on the power of information. He then construes the words more broadly: printing will destroy the transcendant power of architecture. "From the origin of things until the fifteenth century of the Christian era inclusively, architecture was the great book of humanity, the principle expression of man in his various states of development." (175) Hugo relates the beginnings of textual codes (in letters, hieroglyphs) to the design of ancient structures. 12 The most extended of his examples is Jerusalem:

The temple of Solomon, for example, was not simply the binding of the holy book, it was the holy book itself. Upon each of its concentric precincts the priests could read the word translated and manifest before their eyes, and they followed its transformations from sanctuary to sanctuary until they grasped it in the last tabernacle under its most concrete form, which was still architecture: the Ark. Thus the Word was enclosed in an edifice, but its image was upon its covering [enveloppe] .... (176)

With the coming of the Renaissance in the fifteenth century, architectural form as the prime conveyer of a culture's knowledge of itself (as Hugo presents it) yielded to the word, disseminated by a new technology and containing the seeds of revolutionary, destabilizing ideas: "Human thought discovered means of perpetuating itself not only more durable and resistant than architecture, but also simpler and easier. ... The invention of printing is the greatest event in history. It is the mother revolution." (182)

This redirection reduced the innate meaning of style in architecture: "Following the discovery of printing, architecture little by little withers .... It no longer expresses society in any essential way; ... from the Gallic, the European, the indigenous, it becomes Greek and Roman, from the true and the modern [it becomes] pseudo-antique. It is this decadence that is called the renaissance."(183) The irony underlying this passage is that the Renaissance set in motion the development of a literary culture (leading ultimately to the novel) 
whose literate perceptions of pre-Renaissance "indigenous" architecture - as in Hugo's work are necessarily historicist and "pseudo-antique."

Like many other architectural critics of the nineteenth century, Hugo admits the possiblity of a new age, of a revival in modern architecture, even as he decries its contemporary decline and advocates the preservation of the remaining, indigenous artifacts of an earlier era. Hugo is, perhaps, unique in the trenchant way in which he expresses his main point: "Let no one be mistaken: architecture is dead, dead without return, killed by the printed book, killed because it endured less; killed because it cost more." (186) "The great accident of an architect of genius may occur in the twentieth century, as that of Dante did in the thirteenth; but architecture will never again be the social art, the collective art, the dominant art. ... And if, hereafter, architecture should accidently revive, it will no longer be the master. It will submit to the law of literature . . ..” (187)

Hugo projects both a regret for the loss of medieval architecture's power and a sense of superiority in the writer's ability to control the perception of the authentic and inauthentic in architecture. But even more, the writer of the nineteenth century has the power, Hugo suggests, to refashion national history from the stones of ancient monuments. The first two chapters of Book Three of Notre Dame are devoted to the layering of history in architecture, first in the cathedral itself, and then in the city as seen from the cathedral. In both instances Hugo describes a richness of time and texture, and then he states that the greatest attributes of church and city have been lost to neglect and indifference, just as architecture has been displaced from its central role in human consciousness.

Hugo's comments on architecture are polemical, debatable, and passionately engaged in the cause of preservation, which he sees as a means of preserving a people's truth about itself. 13 The writer gives meaning to mute historic structures in a literate age, and at the same time uses architecture as a symbolic structure for meaning within his own work. Although the reputation of Notre Dame has waned in this century, it was widely read in the nineteenth; and one can assume that it was well known, particularly in the 1830s, to a Russian literary elite that avidly read French novels. 14

It was at this time that major Russian writers began their own forays into commentary on architecture as a historical cultural record. Professional literati and writers such as Nikolai Gogol, an amateur of architecture, and Fedor Dostoevskii, trained as an engineer, were to produce the most incisive Russian architectural commentary of the middle decades of the nineteenth century. Concurrently, architectural style for the large number of buildings required for urban growth became increasingly a matter of facade decoration in a pastiche of historicist decorative motifs. With the rise, however tenuous, of a capitalist society and an economy based on individual rather than state initiative, the tastes of architect as well as patron were formed within a new, literate awareness of the possible variety of distinctive styles.

Thus as we approach the theme of historicism in nineteenth-century architecture, we are confronted with a paradox: on the one hand, historicist architectural styles are expected to represent and embody a national image that ipso facto is situated in a preEnlightenment, medieval era - whether in France, England, Germany, or Russia. But if architecture's mission is to evoke historical associations, the content of the decorative image must be provided not by architects, but by the writer, the ideologue, the historian. At the extreme, the building facade becomes a text whose representation supercedes 
tectonic clarity, unity, or even practicality. In historicism the triumph of the printed word over architecture is complete at the very moment in which architecture is exhorted to imitate its distinctive pre-Gutenberg past. (In Russia books were printed by the second half of the sixteenth-century, yet the medieval mentality is often assumed to have persisted until the time of Peter I.)

Gogol provides the significant example in his essay, published in 1835, on contemporary architecture, in which he writes of the fragmentation of social and aesthetic consciousness in the new age: "Our age is so petty, its desires are so dispersed, our knowledge is so encyclopedic, that we can not concentrate our thoughts on one subject; and against our will we split all our creations into trifles and charming toys. We have the marvelous gift of making everything insignificant."15

Yet Gogol continues with an extreme architectural vision that is dispersed, encyclopedic - and perhaps trivialized. In opposition to the universal measure of neoclassicism, he appeals for a visually stimulating urban architecture composed of all styles: "A city should consist of varied masses, if you will, in order to provide pleasure to the eye. Let there be gathered in it more diverse tastes. Let there rise on one and the same street something somber and Gothic; something eastern, burdened under the luxury of ornament; something Egyptian, colossal; and something Greek, suffused with slender proportions." (57) Function is supplanted by the creation of an aesthetic cityscape to enlighten as well as delight its inhabitants.

As for the person capable of designing this new environment:

The architect-creator should have a deep knowledge of all forms of architecture. He least of all should neglect the taste of those peoples to whom we usually show disdain in artistic matters. But in order to master the idea, he must be a genius and a poet.

Gogol's romantic concept of the creative architect seems remote from Russian practice, but his predilection for Gothic architecture was shared by a number of Russian critics and architects including Aleksandr Briullov, the one contemporary architect whose work Gogol praised. (61) Although an imaginative, idiosyncratic form of pseudo-Gothic architecture had flourished in Russia during the reign of Catherine the Great, the post-classical Gothic revival not only was more widely applied, but also appeared specifically as an antidote to neoclassicism. Indeed, the Gothic Revival can be considered the first stylistic development after neoclassicism to lay claim to both aesthetic and historical significance in its own right. For nineteenth-century historicism the Gothic Revival also served as a stimulus for reinterpreting medieval Russian architecture.

Gogol's essay concludes with a proposal for an architectural street in a nation that still had the vaguest sense of its own architectural history. Traversing the ages of civilization reflected in the art of building (cf. Hugo's perception of Paris in Notre Dame), this ideal street culminates in Gothic architecture, the "crown of art," and the promenade ends with some yet undefined new style. "This street would become in a certain sense a history of the development of taste, and anyone too lazy to leaf through weighty tomes would only have to stroll along it in order to find out everything." (59)

There is not in this fantasy one mention of medieval Russian architecture, in any of its manifestations; and the article's references to Russian neoclassicism are not flattering. Gogol praises the cathedrals of Milan and Cologne as well as the Islamic architecture of India; yet the "everything" that Gogol's cultured but indolent Russian might inspect includes nothing from 
eleventh-century Kiev or Novgorod, nothing from twelfth-century Vladimir or sixteenth-century Moscow. Gogol's fascination with architecture and its history (he had at one time studied the architecture of the ancient world) did not extend to Russia. His boulevard of architectural history was a means of imagining that which Russia apparently did not have - a history, not simply an architectural chronicle, but a history of a people as revealed through its architecture.

And yet, by the beginning of the nineteenth century, expeditions to the Russian countryside sought the artifacts of that history. In the 1830s the Academy of Arts, a bastion of European training, had commissioned a survey of prePetrine monuments to be compiled by the artist Fedor Solntsev (1801-1892), whose work played an important role in publicizing early Russian architecture. 16 During the following decade the interest in rediscovering the Russian architectural heritage received significant support from Ivan Snegirev (1793-1868), a professor of Classics at Moscow University but also an amateur of medieval Russian history. In 1848 Aleksei Martynov and Snegirev began to publish their influential series Russian Antiquity (Russkaia starina), which contained detailed descriptions of medieval monuments. 17

It is, therefore all the more curious that in the middle decades of the nineteenth century, Petersburg - not medieval Muscovy - served more readily to validate Russia's position as a nation with a significant history. This paradox is illuminated in Fedor Dostoevskii's "Petersburg Chronicle" for June 1, 1847. In commenting on the advent of spring to the northern capital, the flaneur (the roving observer that is Dostoevskii's narrative persona) describes a city in the throes of growth: "Crowds of workers with plaster, with shovels, with hammers, axes, and other instruments dispose themselves along Nevskii Prospekt as though at home, as though they had bought it; and woe to the pedestrian, flaneur, or observer who lacks a serious desire to resemble Pierrot spattered with flour in a Roman carnival."18

Similar motifs of urban expansion and change reappear in the novelist's post-exile work, most notably Crime and Punishment, where they form an integral part of the psychological environment. The preceding passage, however, veers into a discursus on the built environment as history, a text whose decoding leads to the past as an expression of native identity. With summer approaching and cultured society leaving the town:

What remains for those citizens whose captivity forces them to pass their summer in the capital? To study the architecture of buildings, to how the city is being renewed and built? Of course this is an important occupation and indeed even edifying. Your Petersburger is so distracted in the winter, and has so many pleasures, business, work, card-playing, gossip and various other amusements - besides which there is so much dirt - that he would hardly have the time to look around, to peer into Petersburg more attentively, to study its physiognomy and read the history of the city and all our epoch in this mass of stones, in these magnificent edifices, palaces, monuments [emphasis added - W.B.]. After all, it would hardly come into anyone's head to kill valuable time with such an absolutely innocent and unprofitable exercise. (24)

The irony here is ambiguous, since Dostoevskii's subsequent work uses architecture as an extension and reflection of the contemporary mental state of individual characters as well as entire collectives - hence the "Petersburg theme." Furthermore, by the time of Dostoevskii's early work, the city's architecture reflected only slightly more than a century of 
history, and that often in deliberate contrast to the cultural traditions of the pre-Petrine period. Although sensitive to the psychological impact of urban architecture, Dostoevskii showed little interest in architectural historicism as a means of reclaiming a sense of Russianness that presumably resided in pre-modern (i.e., prePetrine) history.

Dostoevskii's ambivalent - or highly selective - attitude toward history is developed in the subsequent passage of his June 1 entry in the Petersburg Chronicle. At this point Dostoevskii presents the historical approach to architecture through the comments on Russian monuments contained in La Russie en 1839, by the Marquis de Custine. Although been banned in Russia, the book was nonetheless widely known in intellectual circles and is the unmistakable source of Dostoevskii's references:

Incidentally, a study of the city is really not a useless thing. We don't exactly remember, but sometime ago we happened to read a certain French book, which consisted entirely of views on the contemporary condition of Russia. Of course it is already known just what foreigners' views on the contemporary condition of Russia are; somehow up to now we stubbornly do not submit to being measured by a foreign yardstick. But despite that, the renowned tourist's book was eagerly read by all Europe. Among other things, it stated that there is nothing more lacking in character than Petersburg architecture; that there is nothing especially striking about it, nothing national [Dostoevskii's emphasis], and that the entire city is a hybrid caricature of several European capitals. And finally, that Petersburg, if only in an architectural sense, represents such a strange mixture, that one cannot cease to exclaim with amazement at every step. (24)
InDostoevskii's paraphrase, Custine portrays Petersburg as an architectural hybridization similar to the one Gogol had envisioned, but had not found in Petersburg: "Greek architecture, Roman architecture, Byzantine architecture, Dutch architecture, Gothic architecture, architecture of the rococo, the latest Italian architecture, our Orthodox architecture - all this, according to the traveler, whipped up and shaped into a most entertaining form, and in conclusion not one genuinely beautiful building!"19

Dostoevskii would later publish similar views on the hybrid nature of Petersburg architecture as a barometer of social confusion in his Diary of a Writer. Of more immediate interest, however, is his reaction to Custine's claim that the architecture of Petersburg lacks an authentic, appropriate style. Despite his defensive manoeuvre ("we know what foreigners' views of Russia are worth"), Dostoevskii seems to revel in Custine's description of the city's architectural palette. Although Custine criticized the aesthetics of Petersburg, he was also amazed at the city's appearance, which combined stylistic variety with monumental uniformity. 20

Furthermore, Custine saw the building of Petersburg as both validated by history and anticipating it:

Elsewhere great cities are made in memory of great deeds of the past. Or, while cities make themselves with the help of circumstances and history, without the least apparent cooperation of human calculation, Saint Petersburg with its magnificence and immensity is a trophy elevated by the Russians to their power yet to come; the hope that produces such efforts seems to me sublime! Not since the Temple of the Jews has the faith of a people in their destiny wrested from the earth something more marvelous than Saint Petersburg. And what renders this legacy made by a man to his 
ambitious country truly admirable is that it

has been accepted by history. (267-68)

The reference to the Temple in Jerusalem is particularly apt in view of the Zion motif in medieval Russian culture and architecture, as well as in Dostoevskii's own subsequent work. Yet the more peculiar aspect of the preceding passage is its comment on Petersburg as a city both preparing for history and having been accepted by it. In this scheme there are two levels of history: a universal history of established civilization and culture, and the history of Russia, existing in tenuous relation to the former.

Custine, like Dostoevskii, sees historical meaning in the stones of Petersburg. In commenting on the forbidding form of the Mikhailovskii Castle, in which the Emperor Paul was assassinated in 1801, Custine notes in his ninth letter: "If men are silent in Russia, the stones speak and speak in a lamentable voice. I am not surprised that the Russians fear and neglect their old monuments: these are witnesses of their history, which more often than not they would wish to forget." (259) Yet there were, in fact, no "vieux monuments" in Petersburg: the Mikhailovskii Castle, for example, was completed less than four decades before Custine's journey. 21 Furthermore, it is clear from subsequent parts of Custine's narrative - particularly in Moscow - that much had indeed survived from Russia's distant, turbulent architectural past.

Throughout Custine's account the specific meaning of "histoire" can only be determined by context - in the preceding case, the recent political history of the imperial regime. In the same sense, no doubt, Dostoevskii advised his readers in 1847 to ponder the history of their city, whose imperial architecture - despite its recent provenance - can be defined as a historical text begun by Peter and decipherable by the contemporary resident or visitor. Yet Custine also describes Peter's great vision, whose tangible form derived from so many foreign sources, as an aggression directed toward the West ("contre l'Europe une ville ... pour dominer le monde"). Even in its approach toward integration with Europe, even in its new western-style capital, Russia is potentially hostile, alien, and separate.

The ramifications of Custine's thought will achieve their greatest complexity only when he reaches Moscow, and begins a sustained, often deliberately contradictory, dialogue on the fate of Russia - notably as interpreted in the architecture of the Kremlin and other monuments. Paradoxically, it is Custine, not Dostoevskii, who reads medieval Russian architecture as Hugo had read that of fifteenthcentury Paris. That, however, is the topic for another paper. Whatever Custine's ultimate fascination with Moscow, the counterpoint of Custine and Dostoevskii in 1847 demonstrates that Petersburg is modern Russia's first "historical" city, with an architecture that reveals purpose and development toward a concept of nationhood. Dostoevskii realized that Russia's existence as a great nation - and therefore its identity, cultural as well as political - depended on the Peter's turn to the West.22 This may explain the scant "reading" that the great Russian writer gave to medieval Russian architecture, picturesque and stimulating for foreign travelers such as Custine, but of faint relevance - so it then seemed - to Russia's destiny.

\section{References}

1. For an analysis of the design and symbolism of the Cathedral of the Intercession, see William Craft Brumfield, A History of Russian Architecture (New York: Cambridge Univ. Press, 1993), pp. 122-29. 
2. An example of this process of secularization within the church itself is James Cracraft, "Feofan Prokopovich,” J.G. Garrard, ed., The Eighteenth Century in Russia (Oxford, 1973), pp. 75-105.

3. Brumfield, History, pp. 251-53.

4. On the Admiralty Quay project, with Rossi's statement, see V. Kochedamov, "Proekt naberezhnoi u Admiralteistva Zodchego K. I. Rossi,” Arkhitekturnoe nasledstvo, 4 (1953): 111-14.

5. For a broader discussion of this process of local revivalism in western Europe, see Eric Hobsbawm and Terence Ranger, eds., The Invention of Tradition (Cambridge: Cambridge Univ. Press, 1983), with particular reference to Prys Morgan, "From a Death to a View: The Hunt for the Welsh Past in the Romantic Period," pp. 43-100. For an example of the growing Russian literature on this topic, particularly as it pertains to architecture, see E. I. Kirichenko, Arkhitekturnye teorii XIX veka v Rossii (Moscow, 1986), pp. 37-48.

6. Aleksei Martynov, "Rech' ob arkhitekture v Rossii do XVIII stoletiia, govorennaia uchenikom pervogo klassa Alekseem Martynovym," in Otchet Moskovskogo Dvortsovogo Arkhitekturnogo uchilishcha za 1836 i 1837 gody i rechi, govorennye na akte onogo (Moscow, 1838), pp. 1-12.

7. Khudozhestvennaia gazeta, 1838, 12:393-94. See also E. A. Borisova, Russkaia arkhitektura vtoroi poloviny XIX veka (Moscow, 1978), p. 92.

8. Khudozhestvennaia gazeta, 1840, 3:17. Although unsigned, the article may have been written by Nestor Kukolnik, an editor of the paper who frequently commented on architecture. See A. L. Punin, Arkhitektura Peterburga serediny XIX veka (Leningrad, 1990), p. 17.

9. For a theoretical and historical examination of these developments in nineteenth-century historiography, see Hayden White, Metahistory: The Historical Imagination in Nineteenth-Century Europe (Baltimore, 1973).

10. The relation between architecture and the larger context of literary criticism and scientific positivism in Russia during the nineteenth century is explored in E. I. Kirichenko, "Problema natsional'nogo stilia v arkhitekture Rossii 70-kh gg. XIX v.," Arkhitekturnoe nasledstvo, 25 (1976): 135-37; and idem, "Problemy stilia i zhanra v russkoi arkhitekture vtoroi chetverti XIX v.," Arkhitektura SSSR, 1983, Nos. 3-4, pp. 112-15. A broader analysis of the literary aspects of the relation appears in E. A. Borisova, "Nekotorye osobennosti vospriiatiia gorodskoi sredy i russkaia literatura vtoroi poloviny XIX v.," in G. Iu. Sternin, ed., Tipologiia russkogo realizma vtoroi poloviny XIX veka (Moscow, 1979), pp. 252-85. In English, see William Craft Brumfield, The Origins of Modernism in Russian Architecture (Berkeley, 1991), pp. xix-xxii; 1-46.

11. Victor Hugo, Notre-Dame de Paris (Paris: Gallimard, 1975), p. 8. Page references for subsequent quotations from this edition are given in parentheses. English translations are by the author.

12. A attempt to define a connection between edifice and text, architecture and verbal language, from antiquity to the present, is John Onians, "Architecture, Metaphor, and the Mind," Architectural History, 35(1992): 192-207. Although the article shows no dependence on Hugo's work, it includes a number of examples from ancient cultures similar to those in the chapter "Ceci tuera cela."

13. On Hugo's interest in architecture as visual record and potential text, see Philippe Hamon, Expositions: Literature and Architecture in Nineteenth-Century France, translated by Katia SainsonFrank and Lisa Maguire (Berkeley, 1992), pp. 7, 53-55.

14. Hugo's reception in Russia is analyzed in M. P. Alekseev, "V. Giugo i ego russkie znakomstva," Literaturnoe nasledstvo, 31-32 (19- ): 777-915. Dostoevskii wrote the preface for the first complete 
Russian translation of Notre Dame in 1862. See Polnoe sobranie sochinenii v tridtsati tomakh, vol. 20 (Leningrad, 1980), pp. 272-78.

15. Gogol', N. V. "Ob arkhitekture nyneshnego vremeni," in Sobranie sochinenii v shesti tomakh, vol. 6. (Moscow, 1959), p. 51. Subsequent references to this source are given in parentheses in the text.

16. T. A. Slavina, Issledovateli russkoi arkhitektury, (Leningrad, 1983), pp. 42-44.

17. The first volume of Russkaia starina appeared in 1848, the last (No. 6) appeared in 1860. Thereafter Martynov and Snegirev continued to collaborate on similar publications until the end of the 1880s. See Slavina, Issledovateli, p. 70.

18. Peterburgskaia letopis'," in F. M. Dostoevskii, Polnoe Sobranie sochinenii v tridtsati tomakh, vol. 18 (Leningrad, 1978), p. 23. Subsequent references to this source are given in parentheses in the text.

19. Dostoevskii probably refers to the opening passage of Custine's eighth letter, in which he presents his initial impressions of Petersburg. Similar views are presented in a description of the palaces and buildings of the central squares in the eleventh letter. Dostoevskii would likely have known the second, "corrected and expanded" edition of Custine's work, which appeared in 1843 and was rapidly smuggled into Russia. See Dostoevskii, Polnoe Sobranie, 18:226n24; also P. V. Annenkov, Literaturnye vospominaniia (Moscow, 1960), pp. 256-57. The reaction of Vissarion Belinskii, Alexander Herzen, and Dostoevskii to Custine's work is analyzed in E. I. Kiiko, "Belinskii i Dostoevskii o knige Kiustina 'Rossia v 1839',' G. M. Fridlender, ed., Dostoevskii. Materialy i issledovaniia, vol. 1 (Leningrad, 1974), pp. $189-99$.

20. See Le Marquis de Custine, La Russie en 1839, second edition (Paris, 1843), 1: 225-28; 34449. Subsequent references to this source are given in parentheses.

21. On the design and construction of the Mikhailovskii Castle, see V. K. Shuiskii, Vinchentso Brenna (Leningrad, 1986), pp. 120-64.

22. For commentary on the development of this theme in Dostoevskii's later work, see Brumfield, "The West and Russia: Concepts of Inferiority in Dostoevsky's Adolescent," in Russianness: Studies on a Nation's Identity, ed. Robert Belknap (Ann Arbor, 1990), pp. 144-53. 


\title{
Виктор Гюго, маркиз де Кюстин \\ и Федор Достоевский: \\ архитектура как исторический текст
}

\author{
У.К. Брумфильд \\ Университет Тулейн \\ США, Луизиана, Новый Орлеан
}

\begin{abstract}
В статье рассматривается восприятие архитектуры и архитектурного стиля в Европе ХІХ века как выражение истории и культуры, которые не могут быть полностью представлены вербальными, художественными текстами. Данная концепция особенно активно использовалась в обсуждениях национальной идентичности. С одной стороны, архитектура является отражением начиональной культуры, но в то же время она способствует последующемувыражению этойкультуры. В этой связи появились критические интерпретации архитектурного стиля эклектики и историзма. В статье рассматриваются истоки понятия историзма в романе Виктора Гюго «Нотр-Дам де Пари» и его развитие в работах Николая Гоголя, Федора Достоевского и маркиза де Кюстина.
\end{abstract}

Ключевые слова: архитектурная стилизачия, историзм, эклектика, Карло Росси, Виктор Гюго, Нотр-Дам де Пари, Николай Гоголь, Алексей Мартынов, Федор Достоевский, Париж, Санкт-Петербург, Москва.

Научная специильность: 24.00.00 - культурология. 